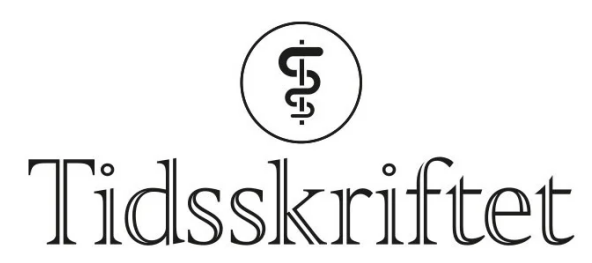

DEN NORSKE LEGEFORENING

\title{
Kai-Håkon Carlsen
}

\author{
MINNEORD
}

TERJE ROOTWELT

IREN MATTHEWS

GEIR HÅLAND

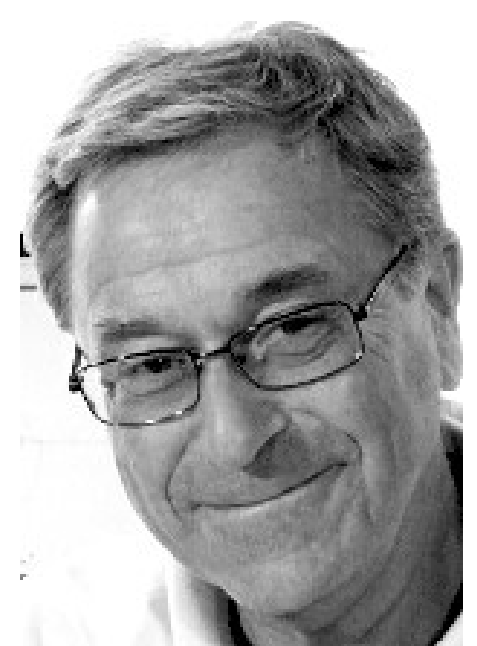

Vår kjære kollega og venn Kai-Håkon Carlsen døde 15. september etter kort tids sykdom. En nestor i norsk barnemedisin er gått bort.

Kai-Håkon ble født i Moss i 1946. Etter gjennomført medisinstudium i Oslo og turnustjeneste spesialiserte han seg $\mathrm{i}$ barnemedisin, et valg han aldri angret på. Hans hovedinteresse var luftveissykdommer og allergi hos barn, og han var overlege ved barneavdelingen ved Ullevål sykehus før han ble leder av Voksentoppen senter for astma og allergi. Han var en kunnskapsrik og omsorgsfull doktor som barn og foreldre raskt fikk tillit til.

I 1988 disputerte han for den medisinske doktorgraden på sammenhengen mellom virusinfeksjoner og astma hos barn. Dette ble starten på en imponerende akademisk karriere. Med en kombinasjon av engasjement, kreativitet, stahet og stor arbeidskapasitet ble han en av nestorene i pediatrisk lungemedisin og allergologi nasjonalt og internasjonalt. Mer enn 300 artikler publiserte han, og 23 stipendiater har hatt gleden av å ha ham som en inspirerende veileder. 
Han hadde en rekke verv i den europeiske og amerikanske lungeforeningen og var blant annet leder av Paediatric Assembly of the European Respiratory Society og ledet og utviklet European Respiratory School. Han var leder av Norsk forening for allergologi og immunpatologi, en forening han også ble utnevnt til æresmedlem av. Han deltok i utformingen av et utall nasjonale og internasjonale retningslinjer innenfor sitt brede interessefelt. Dette inkluderte også luftveissykdommer hos idrettsutøvere, og han ble professor både ved Universitetet i Oslo og ved Norges idrettshøgskole. Her fikk studentene glede av hans omfattende kunnskap og formidlingsevne.

Den viktigste inspiratoren for Kai-Håkon var hans kjære Karin. De delte kjærligheten til klassisk musikk og engasjementet for barn med allergi og lungesykdommer. Sammen opprettet de forskningsgruppen Oslo Research Group of Asthma and Allergy in Children; the Lung and Environment (ORAACLE), et samarbeid mellom flere forskningsinstitusjoner. Kai-Håkon hadde et omfattende nettverk, og mange studier ble gjennomført i samarbeid med ledende internasjonale forskningsmiljøer. Forskningsgruppens arbeid har vært med på å endre vår forståelse og behandling av disse sykdommene.

I tillegg til de dype faglige sporene Kai-Håkon har satt, vil vi huske ham for hans vennlige og imøtekommende vesen. Han var den rause og inkluderende som alltid tok seg tid når vi banket på døren, enten det gjaldt et faglig spørsmål eller bare behov for en liten prat. Vi vil savne Kai-Håkon.

Våre tanker går til Karin, barn og barnebarn.

På vegne av kollegaer på Barne- og ungdomsklinikken ved Oslo universitetssykehus

Publisert: 8. november 2021. Tidsskr Nor Legeforen. DOI: 10.4045/tidsskr.21.0730

(C) Tidsskrift for Den norske legeforening 2023. Lastet ned fra tidsskriftet.no 26. april 2023. 